\title{
Justice in Compensation; Family vs. Non-family Business HR Issues
}

\section{Ömer YAZICI iD a}

a Bayburt University, Vocational School of Health Services, Bayburt, Türkiye. omeryazici@bayburt.edu.tr

\begin{tabular}{|c|c|}
\hline ARTICLE INFO & ABSTRACT \\
\hline \multirow{3}{*}{$\begin{array}{l}\text { Keywords: } \\
\text { Family business } \\
\text { Organizational justice }\end{array}$} & \multirow{3}{*}{$\begin{array}{l}\text { Purpose - Present study aims to shed light on some of the HR issues of family businesses, including } \\
\text { organizational justice, pay satisfaction, and turnover intentions of family business employees } \\
\text { compared to non-family business employees. }\end{array}$} \\
\hline & \\
\hline & \\
\hline Turnover & \multirow{3}{*}{$\begin{array}{l}\text { Design/methodology/approach }-301 \text { family and non-family business workers from USA were } \\
\text { surveyed. Regression analysis used to test the relationships and MANOVA was used to test } \\
\text { difference between groups. }\end{array}$} \\
\hline & \\
\hline & \\
\hline Job Satisfaction & \multirow{2}{*}{$\begin{array}{l}\text { Findings - Results show that while family business employees are less satisfied with benefit } \\
\text { packages, their distributive justice perceptions, pay perceptions, and turnover intentions are not } \\
\text { significantly different from non-family employees'. Furthermore, moderation analysis reveals that } \\
\text { family involvement does not significantly change the relationship level between distributive justice, } \\
\text { pay perceptions and turnover intentions. }\end{array}$} \\
\hline Pay Satisfaction & \\
\hline Received 3 May 2020 & \multirow{5}{*}{$\begin{array}{l}\text { Discussion - According to our results family business managers should be careful with benefit } \\
\text { packages and pay attention to keep a just environment to prevent possible increased turnover. } \\
\text { Furthermore, family business managers should keep familiness impact under control so that it does } \\
\text { not reach to a significant level to impact justice perceptions and turnover intentions. While family } \\
\text { business literature is developing constantly, non-family employee issues, particularly blue-collar } \\
\text { worker issues are very limited. This study showed that family businesses are neither good nor bad } \\
\text { regarding blue-collar employee HR issues and family and non-family business employees are not } \\
\text { different in their justice perceptions. This valuable contribution should lead researchers to seek } \\
\text { additional constructs to evaluate causes of family firm HR issues. }\end{array}$} \\
\hline Revised 21 May 2020 & \\
\hline Accepted 15 June 2020 & \\
\hline Article Cla & \\
\hline Research Article & \\
\hline
\end{tabular}

\section{INTRODUCTION}

Researching and understanding family business is very important, mainly because more than $80 \%$ of companies in the world are family enterprises (Gersick, Davis, Hampton, \& Lansberg, 1997; Kachaner, Stalk, $\&$ Bloch, 2012). In addition to that, about $80 \%$ of the labour forces in family firms are filled with non-family employees (Tabor et al., 2018; Mass Mutual Financial Group, 2007). Due to unexpected results of family involvement into employee relations Neckebrouck, Schulze, \& Zellweger (2018) are asking the inevitable question: "Are family firms good employers". Unfortunately, studies on Human Resource (HR) practices and their effects on organizational justice and employee satisfaction are limited for small businesses and even rarer in the family business context (Barnett \& Kellermanns, 2006; R. S. Reid \& Adams, 2001). Previous researchers examined family firm compensation practices from perspectives of altruism, agency (Lubatkin, Ling, \& Schulze, 2007), or qualitative based observations (Beehr, Drexler, \& Faulkner, 1997). Barnett and Kellermanns (2006) offered a conceptual model to investigate how family intervention affects the human resource practices and the justice perceptions of non-family employees. Though employment compensation research has significant practical implications (Carrasco-Hernandez \& Sánchez-Marín, 2007) such as that a majority of total operating expenses come from employee compensation (Gomez-Mejia \& Balkin, 2006), there is limited work on this topic in family business literature. This work contributes to the body of knowledge by investigating the satisfaction of employees who are not part of the controlling family, specifically blue-collar workers, with the practices of compensation in the family businesses. Reasons for selecting blue-collar workers are first to investigate a far less explored section of family firm human resources, second it is suggested that blue-collar workers have different indicators of turnover intentions than white-collar workers and last, it is expected to see lower turnover intentions among blue-collar employees of family firms (Gottschalck et al., 2019). Having secure working environments and sustainability-oriented personnel planning in family firms is significantly 


\section{Ö. Yazıc1 12/2 (2020) 1655-1667}

important for blue-collar workers. (Gottschalck et al., 2019; Bassanini et al., 2013). Blue-collar workers differ from white-collar workers in proximity to the owning family. While white-collar workers work in the same office with family members and exchange emotions and contribute decision making processes, blue-collar workers feel the family influence only by companywide policies. Hence it is expected to observe different organizational behaviour from those two groups of workers.

It is theoretically and practically supported that top management incentive systems are applied through lower levels of management as a form of monitoring (Fama \& Jensen, 1983; Werner \& Tosi, 1995; Willams et al., 2008). Moreover, studies analyzing non-family employees of family businesses argue that not only do family firms pay their top management teams and managers less, but it has also been shown that others in whitecollar positions are also paid less (Bandiera et al., 2015; Gomez-Mejia, Larraza-Kintana, \& Makri, 2003). Research shows that many companies maintain certain proportions between the top and lowest paid, and since family CEOs tend to set themselves for low pay and leave more money to the company (Gomez-Mejia, Nuñez-Nickel, \& Gutierrez, 2001), it is expected to see low pay levels for blue-collar family firm employees (Carrasco-Hernandez \& Sánchez-Marín, 2007). According to Michiels, (2017) for family firms, compensation issue is at the centre of many problems and a very important topic to study.

In response to the lack of empirical analysis on family business blue-collar workers and unexplored distinctions between family and non-family firms, the purpose of this study is to explore how family firms differ from non-family firms regarding blue-collar workers' pay perceptions, justice perceptions and compensation satisfaction. Compensation is particularly important for family SMEs but still there is a lack of empirical research (Cruz et al., 2011) while many available ones are focused only on recommendations (Michiels, 2017). The main research question seeks to explore whether family firm blue-collar workers are satisfied with their compensation (including benefit packages) and to compare the level of distributive justice in family and non-family firms. To test the relationships and compare the differences among groups, we will perform regression analysis and MANOVA tests. The rest of the paper proceeded as follows; section two provides a detailed literature review and hypotheses. Methodology is covered in section three. Section four provides an analysis of results. Section five discusses results while section six includes managerial implications. Section seven outlines limitations and future research suggestions, and section eight contains the conclusion.

\section{LITERATURE REVIEW AND THEORY DEVELOPMENT}

\section{HR Practices of Family Businesses}

Finding reasons behind the success of family businesses despite managerial limitations is one of the biggest challenges of family business researchers. As it is true for all companies, Chrisman, Chua, \& Litz (2003) and Chua, Chrisman, \& Sharma (2003) concluded that attracting qualified non-family employees and fostering value-creating behaviours in this group is critical. Barnett \& Kellermanns (2006) argued that the family might have a direct effect on non-family employee's justice perceptions, but its biggest impact might be on development and implementation of human resource policies and procedures. Schulze, Lubatkin, \& Dino (2003) suggest that family firms within the first generations, where the founders are still in charge, have strong altruism, which leads to strong family ties in the business and foster loyalty and commitment to both the firm and family (J. L. Ward, 2011). On the contrary, Barnett \& Kellermanns (2006) suggested that altruism, similar to culture, could have negative effects on the fairness of HR practices. Although in that study, Barnett \& Kellermanns (2006) argued that family intervention might create problems for non-family employees' justice perceptions. Carsrud (2006) argued that injustice, unfairness, and inequalities can create problems for family as well as non-family employees. Supporting the Barnett \& Kellermanns' (2006) argument, Astrachan \& Kolenko (1994) claimed that family firms use formal HR practices and procedures for non-family employees more than they do for family employees.

While the number of empirical studies on human resource practices of family-owned businesses and their effects on performance is relatively limited (R. Reid, Morrow, Kelly, \& Mccartan, 2002), Carlson, Upton, \& Seaman (2006) found that there is a significant relationship between human resource management practices and high performance of family business while others (i.e., Astrachan \& Kolenko, 1994) suggested that human resource practices and revenues of family businesses are positively related. According to Madison et al., (2017) lack of perceived organizational justice between family and non-family employees could results in lowered 


\section{Ö. Yazıc1 12/2 (2020) 1655-1667}

firm performance. In addition to that, some researchers (i.e., John L. Ward, 1988) suggested that family businesses might be able to create a more family-oriented workplace to increase the loyalty of their employees. Perceptions of leadership responsibilities of blue- and white-collar workers in family and non-family firms are key determinants of their turnover intentions and indicators to explain the difference between family and nonfamily firms (Gottschalck et al., 2019). Staying in close touch with the owning family could result in reliability and appreciation and would results in decreased turnover intentions (Pittino et al., 2016)

On the other hand, researchers argue that distributive justice is a major indicator of pay satisfaction (DeConinck \& Stilwell, 2004), and it is related to job satisfaction and turnover intentions through a relationship with pay, benefits, and rewards (Alexander \& Ruderman, 1987; Haar \& Spell, 2009; Konovsky, Folger, \& Cropanzano, 1987). According to studies (i.e Chrisman et al., 2017; Memili et al., 2013), family firms, unlike non-family firms, do not rely on incentives to reward and inspire non-family employees. By studying Northern Ireland Small and Medium Enterprises (SMEs), R. S. Reid \& Adams (2001) analysed and compared the HR practices of family businesses with non-family businesses. Results suggested that while family businesses have higher turnover rates, non-family businesses have higher labor costs than family businesses. This might be related to other conclusions of the same study, which suggests that family businesses provide less training to their employees than non-family firms and family firms are not inclined to deal with unions. Also, lower cost might be related to Carrasco-Hernandez \& Sánchez-Marín's (2007) conclusion, which is that family firms pay less to their employees compared to non-family firms.

H1: Compared to non-family firm blue-collar employees, family firm blue-collar employees have lower perceived distributive justice

H2: Compared to non-family firm blue-collar employees, family firm blue-collar employees have greater turnover intentions

\section{Perceived Justice, Pay Satisfaction and Turnover Intentions of Non-family Employees}

Business and family systems are two main points that non-family employees have to deal with while working in a family firm (Tabor et al., 2018). Turnover intentions as well as job embeddedness of non-family employees depends on this twofold taxonomy (Gottschalck et al., 2019). Differed human resource practices of family firms towards family employees (Jennings, Dempsey, \& James, 2018) is a real case in family firms and most important form of this bifurcated HR management is monetary compensation (Samara et al., 2019; Samara \& Arenas, 2017). On the other hand, in their comprehensive literature analysis, Jennings et al., (2018) concluded that while bifurcated HR practices favours the family employees, there are cases that it also favours the nonfamily employees. There have been several studies investigating the satisfaction of family business employees (Bandiera et al., 2015; Block et al., 2015; R. S. Reid \& Adams, 2001). Furthermore, researchers associated organizational justice with a number of work attitudes like job dissatisfaction and turnover intentions (Konovsky et al., 1987). Literature suggests that the connection between organizational justice and attitudinal outcomes in the family firm context is still not clear. Carmon et al. (2010) concluded that a family member and non-family member do not differ in their perceptions of organizational justice. Furthermore, Michiels (2017) studied compensation practices of family SMEs by using 124 small- to medium-sized Belgian family firms and concluded that family firms are not different than others in Belgium. Perceived just promotion or pay will translate to just organization (Sieger, Bernhard, \& Frey, 2011). Moreover, authors concluded that it was more important for employees to be fair in terms of outcome distributions, like pay and promotion, than procedural and interactional justice.

Researchers (i.e., Al-Salemi, 2013) suggest that when perceptions of organizational justice increase, job satisfaction and organizational commitment will increase and intentions to leave will decrease. Ercan (2018) suggested that intrinsic motivations impact job satisfaction much more than extrinsic and promotional factors do. Memili \& Welsh (2012) proposed that when non-family employees do not identify themselves with an organization and disconnect with the organization, they will be more prone to developing turnover intentions. Block, Millán, Román, \& Zhou (2015) studied European communities to investigate the pay satisfaction of family employees and results show that employees, who are not part of the family, are less satisfied in their jobs compared to family member employees. Also, the same study suggested that family members are willing to accept lower wages compared to non-family members while female family members earn more than nonfamily female employees, and male family employees earn less than non-family male employees. Beehr, 
Drexler, \& Faulkner (1997) argued that since family firms prioritize the family members in the company, nonfamily employees are less satisfied with justice in the company, and they feel fewer personal advantages and find no difference in between being a family business employee or non-family business employee. Chen et al., (2011) stated that satisfaction and turnover intentions relationship has been studied thousands of times but still scholars still looking for extant variables to investigate why, how, and when this relationship changes. In this context investigating the family involvement as a moderator for this relationship will enlighten this phenomenon. Furthermore, considering that family firms are notorious with nepotism and other justice issues (Carsrud, 2006), studying justice perceptions and turnover intentions in the light of family involvement will help to capture family firms' uniqueness and heterogeneity.

H3: Compared to non-family firm blue-collar employees, family firm blue-collar employees are less satisfied with compensation packages

H3A: Family firm blue-collar employees are less satisfied with pay (salary)

H3B: Family firm blue-collar employees are less satisfied with benefit packages

H4: Family involvement moderates the relationship between pay satisfaction and turnover intentions.

H5: Family involvement moderates the relationship between distributive justice perceptions and turnover intentions.

\section{METHODOLOGY}

\section{Sample Data}

Data for this study is taken from a broader research project, which is designed to investigate the relationships between pay perceptions and job satisfaction (Nielson, 2014). The sample is drawn from a current list of bluecollar workers who are employed in factories, construction sites, and other manual labour jobs and receive an hourly salary in the United States.

An online survey was used to collect data from respondents. A random sample of the blue-collar workers was selected and invited to participate in the survey by using probabilistic sampling method. Ownership status of the firm (Family vs. Non-family) is self-defined by the respondents of the survey. This method reveals the perceived family firms rather than statistically defined family firms. Survey applicants were asked questions about the perception of justice in the distribution of outcomes, satisfaction about their compensations, and turnover intentions. A computerized structured questionnaire was utilized to gather data from respondents. This questionnaire was delivered electronically to individuals from a list of blue-collar workers. A list of 1,156 contacts was obtained and of the 1,156 surveys distributed, 502 were returned. After eliminating disqualified or incomplete surveys, the final sample size was 301 , which represents a $26 \%$ return rate. This sample was comprised of 301 respondents; 126 (41.8\%) women and 175 (58.1\%) men respondents respectively. To evaluate the nonresponse bias, we applied t-test to compare early and late respondents (Rogelberg \& Stanton, 2007). Results show that early versus late responders did not differ on gender $(t=.867$, Sig $=0.094)$, race $(t=.270$, Sig= $0.941)$, age $(t=-.573$, Sig= 0.268), education $(t=-.281$, Sig= 0.159), region $(t=.205 \mathrm{Sig}=0.205)$, tenure in the organization $(t=-.552$, Sig= 0.273$)$, tenure in the position $(t=-.141$, Sig= 0.260) or income $(t=-.082$, Sig= 0.754$)$.

\section{Variables}

The present study is designed to analyse and compare the perceptions of non-family employees' pay satisfaction, perceived distributive justice, and turnover intentions. MANOVA analysis used to test difference between family business and non-family business in terms of pay satisfaction, distributive justice, and turnover intentions. Furthermore, authors used Factor Analysis to extract factors from the instruments. According to Hair et al. (2010), 0.30 is the minimum acceptable level for each loading and sample; sizes around 300 should take 0.35 or more for statistical significance. To have more parsimonious output, this study kept the minimum level at 0.50 .

Pay satisfaction, which might deteriorate behaviour of employees and cause absenteeism, lack of commitment, lowered productivity, and increased turnover (Nelson et al., 2008), is measured by a 13-item questionnaire developed from Nielson (2014). Using Factor Analysis, we developed a three-factor model: pay satisfaction with pay (PS_Pay), pay satisfaction with comparison (PS_Comparison), pay satisfaction with benefits 
(PS_Benefits). 5 points Likert Scale is applied to all questions, ranging from "strongly disagree" to "strongly agree". PS_Pay factor is measured by questions like, "My / pay is the amount I expect on each check." PS_Comparison factor is measured by questions like, "I am / satisfied with my pay raises that I have received in the past." PS_Benefits factor is measured by questions like, "I am satisfied with the size of my current / salary."

Perceived distributive justice is measured by using a 14-item scale, developed by Heneman \& Schwab (1985) and Dulebohn \& Werling (2007). Factor Analysis revealed a two-factor model: perceived distributive justice based on outcome (PDJ_Outcome) and perceived distributive justice based on expectation (PDJ_Expectation). PDJ_Outcome factor is measured by questions like, "My / company is fair in the way they administer pay" and PDJ_expectation factor is measured by questions like, "My current salary is fair."

Turnover intentions that are mainly affected by pay satisfaction and perceived distributive justice (Al-Salemi, 2013; Konovsky et al., 1987) are measured by a one-item scale which is, "I am hoping to find a new job in the next 1-5 / years." Regression and multiple regression analysis were used to test level of significance between the proposed variables.

Demographics of the respondents were also investigated to explore any impact on above variables. Characteristics of the demographic variables are as follow: gender and race are categorical, age, tenure in the company, tenure in position, and income are continuous variables.

\section{RESULTS AND DISCUSSION}

\section{Analysis}

MANOVA was used to analyse sampling differences between family and non-family business respondents. Results show that there are no differences except in the case of gender. This indicates that the family business sample has a larger male population than female. Since most of the demographics have no significant difference, we do not take any action and continue with caution. Briefly, the sample has equal characteristics for both groups.

Table 1 shows the descriptive statistics such as standard deviations, means, and correlations among the variables. Significant correlations are possible indicators for possible significant relationships. Further analysis reveals significant findings for those highly correlated variables such as income and gender.

To be able to examine the distributive justice and pay satisfaction variables, we applied Factor Analysis to extract the stronger factors. Table 2 shows Factor Analysis results. Analysis resulted in two factors, PDJ_Outcome (perceived distributive justice based on outcome) and PDJ_Expectation (perceived distributive justice based on expectations) for perceived distributive justice, and three factors, PS_W_Pay (pay satisfaction with salary), PS_W_Comparison (pay satisfaction compared to others) and PS_W_Benefits (pay satisfaction with benefits) for perceived pay satisfaction. Furthermore, Table 2 shows reliability measures for those items. All the factors have higher Cronbach Alpha levels than the suggested 0.85 threshold, except Factor 2 (0.712) being at the least acceptable point. Since this is exploratory research, it will be kept with caution. 
Table 1: Descriptive statistics and correlations among variables

\begin{tabular}{|c|c|c|c|c|c|c|c|c|c|c|c|c|c|c|c|c|c|}
\hline & Descriptives & $\begin{array}{l}\text { Mea } \\
n\end{array}$ & $\begin{array}{l}\text { Std. } \\
\text { Dev. }\end{array}$ & 1 & 2 & 3 & 4 & 5 & 6 & 7 & 8 & 9 & 10 & 11 & 12 & 13 & $\begin{array}{l}1 \\
4\end{array}$ \\
\hline 1 & Gender & 1.409 & 0.4924 & 1 & & & & & & & & & & & & & \\
\hline 2 & Race & 4.651 & 0.9906 & 0.034 & 1 & & & & & & & & & & & & \\
\hline 3 & Age & 4.352 & 1.5628 & 0.09 & $0.159^{*}$ & 1 & & & & & & & & & & & \\
\hline 4 & education & 1.545 & 0.7086 & -0.057 & -0.07 & 0.028 & 1 & & & & & & & & & & \\
\hline 5 & region & 2.595 & 1.0076 & 0.08 & -0.015 & 0.025 & -0.04 & 1 & & & & & & & & & \\
\hline 6 & tenure & 2.967 & 1.4648 & -0.018 & -0.013 & $0.352^{*}$ & 0.053 & 0,009 & 1 & & & & & & & & \\
\hline 7 & tenurepos & 2.744 & 1.3308 & 0.007 & -0.005 & $0.332^{*}$ & 0.042 & - & $0.705^{*}$ & 1 & & & & & & & \\
\hline 8 & income & 2.465 & 1.0753 & $0.341^{*}$ & 0.059 & 0.069 & 0.051 & $.122^{*}$ & $.262^{* *}$ & $0.205^{*}$ & 1 & & & & & & \\
\hline 9 & PDJ_OUTCOME & 0 & 1 & -0.095 & -0.046 & -0.104 & - & - & 0.074 & 0.056 & $0.226^{*}$ & 1 & & & & & \\
\hline 10 & PDJ_EXPECTATIO & 0 & 1 & $0.148^{*}$ & 0.016 & $-.123^{*}$ & - & -0.04 & -0.02 & 0.001 & 0.004 & 0 & 1 & & & & \\
\hline 11 & PS_W_PAY & 0 & 1 & - & -0.011 & -0.045 & - & - & $.115^{*}$ & 0.113 & $0.149^{*}$ & $0.748^{*}$ & $-0,002$ & 1 & & & \\
\hline 12 & PS_W_COMPARIS & 0 & 1 & -0.044 & -0.07 & -0.08 & 0.057 & 0.033 & -0.048 & -0.056 & $0.158^{*}$ & $0.434^{*}$ & $0.156^{*}$ & 0 & 1 & & \\
\hline 13 & PS_W_BENEFITS & 0 & 1 & 0.047 & -0.054 & -0.032 & 0.014 & 0.05 & 0.085 & -0.017 & $0.236^{*}$ & $0.271^{*}$ & $-.198^{* *}$ & 0 & 0 & 1 & \\
\hline 14 & FB & 1.674 & 0.4694 & $0.116^{*}$ & -0.109 & -0.107 & 0.024 & 0.009 & -0.059 & -0.112 & 0.037 & 0.023 & -0.107 & 0.01 & - & $.249^{*}$ & 1 \\
\hline
\end{tabular}

** Correlation is significant at the 0.01 level ( 2 tailed).

* Correlation is significant at the 0.05 level (2-tailed).

$\mathrm{N}=301$

It is suggested (Chrisman, Chua, Pearson, \& Barnett, 2012) that family business studies should be able to differentiate family firms from non-family firms. Therefore, we investigated the difference in Table 3. MANOVA results exhibit the difference between family business and non-family business in terms of pay satisfaction, distributive justice, and turnover intentions. Findings do not support Hypothesis 1 nor Hypothesis 2. This indicates that there is no significant difference in distributive justice perceptions and turnover intentions of family business blue-collar employees compared to non-family business blue-collar employees.

Furthermore, Table 3 shows that family business blue-collar employees do not have significantly different pay satisfaction levels compared to non-family business counterparts. On the contrary, family firm blue-collar employees have different benefit package satisfaction levels. Therefore, Hypothesis 3 is partially supported. Further analysis shows that family firm employees are less satisfied with their benefit package than family firm employees $(B=-0.888, S i g=0.000)$. In conclusion, family business blue-collar employees are not significantly different from non-family business blue-collar employees in perceived distributive justice and perceived pay satisfaction, but they are different in perceived satisfaction with benefit packages. 
Table 2: Factor Analysis, Perceived Distributive Justice and Pay Satisfaction

\begin{tabular}{|c|c|c|c|c|c|c|}
\hline Variables & Factor1 & Factor2 & & Factor1 & Factor2 & Factor3 \\
\hline \multirow[t]{2}{*}{ P.D. Justice Variables } & P.D. Justice & P.D. Justice & Pay Satisf. & PS_W_ & PS_W_ & PS_W_ \\
\hline & Outcome & Expectation & Variables & Pay & \multicolumn{2}{|c|}{ Comparison Benefits } \\
\hline PDJ13 & 0.945 & & PS7 & 0.874 & & \\
\hline PDJ12 & 0.935 & & PS12 & 0.863 & & \\
\hline PDJ14 & 0.928 & & PS8 & 0.846 & & \\
\hline PDJ11 & 0.916 & & PS11 & 0.834 & & \\
\hline PDJ3 & 0.911 & & PS13 & 0.742 & & \\
\hline PDJ5 & 0.896 & & PS9 & 0.684 & & \\
\hline PDJ1 & 0.877 & & PS1 & 0.523 & & \\
\hline PDJ4 & 0.810 & & PS3 & & 0.797 & \\
\hline PDJ2 & 0.795 & & PS4 & & 0.781 & \\
\hline PDJ6 & 0.516 & & PS5 & & 0.697 & \\
\hline PDJ9 & & 0.823 & PS6 & & 0.691 & \\
\hline PDJ10 & & 0.793 & PS2 & & & 0.900 \\
\hline & & & PS10 & & & 0.849 \\
\hline Explained Variance & $53.20 \%$ & $12.60 \%$ & & $36.90 \%$ & $23.30 \%$ & $16 \%$ \\
\hline Cronbach Alpha & 0.957 & 0.712 & & 0.941 & 0.855 & 0.879 \\
\hline $\begin{array}{l}\text { Extraction Method: Pr } \\
\text { Rotation Method: Vari } \\
\text { PDJ-Outcome=Perceiv } \\
\text { PDJ-Expectation=Perc } \\
\text { PS_W_Pay=Perceived } \\
\text { PS_W_Comparison=P } \\
\text { PS_W_Benefits=Percei }\end{array}$ & $\begin{array}{l}\text { cipal Compor } \\
\text { hax with Kaise } \\
\text { d Distributive } \\
\text { ved Distributi } \\
\text { atisfaction wit } \\
\text { ceived Pay Sa } \\
\text { ed Satisfactior }\end{array}$ & $\begin{array}{l}\text { alysis. } \\
\text { nalization. } \\
\text { based on Ou } \\
\text { ice based on E } \\
\text { y } \\
\text { on when Com } \\
\text { Benefit Packaq }\end{array}$ & $\begin{array}{l}\text { ions } \\
\text { Others }\end{array}$ & & & \\
\hline
\end{tabular}

Table 4 analyses the impact of family businesses on relationships between pay satisfaction, distributive justice, and turnover intentions. In Model 1, results show that there is a significant negative relationship between outcome-based perceived distributive justice and turnover intentions $(B=-0.451$, sig. $=0.000)$. Adding the family business variable into Model 2 resulted in no significant relationship between family business and turnover intentions, as well as no significant increase in R2 (sig. 0.676 and R2 remained at 0.206). In Model 3, we added the interaction effects of family business and distributive justice perceptions; results also indicate no significant improvement or relationship (sig. 0.888 and 0.278, and R2 changed from 0.206 to 0.209). Results indicate that family ownership does not have a significant impact on the relationship between distributive justice perceptions and turnover intentions for blue-collar workers. 
Table 3: MANOVA Analysis

\begin{tabular}{lll}
\hline Variables & $\mathrm{f}$ & Sig. \\
\hline TOI & 0.416 & 0.519 \\
PDJ_OUTCOME & 0.162 & 0.688 \\
PDJ_EXPECTATION & 3.45 & 0.064 \\
PS_W_PAY & 0.039 & 0.843 \\
PS_W_COMPARISON & 0.977 & 0.324 \\
PS_W_BENEFITS & 19.772 & 0.000 \\
\hline
\end{tabular}

$\mathrm{P}<0.05, \quad \mathrm{R} 2=0.062, \mathrm{~A} . \mathrm{R} 2=0.059$

In the analysis of the perceived pay satisfaction and turnover intentions relationship, family business moderation analysis reveals non-significant results. Table 5 shows that in Model 1, pay satisfaction has a significant impact on turnover intentions. Model 2 analyses whether there is any improvement after family business involvement, and results show that there is no significant impact (sig. 0.955 and R2 stayed at 0.227). In Model 3, the researchers explore the interaction effect for improvement. This is controlled for main effects. Results are also not significant (sig. 0.784, 0.921, and 0.787, R2 stayed at 0.227 ). In conclusion, family involvement does not appear to impact the relationship between pay satisfaction and turnover intentions. Therefore, Hypotheses 4 and 5 are not supported.

Table 4: Moderation Analysis for Distributive Justice

\begin{tabular}{|c|c|c|c|c|c|c|}
\hline \multicolumn{7}{|c|}{ FB Moderation on Distributive Justice } \\
\hline & $\begin{array}{l}\text { Model } 1 \\
\text { Strd. Beta }\end{array}$ & Sig. & \multicolumn{2}{|c|}{$\begin{array}{l}\text { Model } 2 \\
\text { Strd. Beta Sig. }\end{array}$} & \multicolumn{2}{|c|}{$\begin{array}{l}\text { Model } 3 \\
\text { Strd. Beta Sig. }\end{array}$} \\
\hline PDI OUTCOME & -0.451 & $0.000^{* *}$ & -0.450 & $0.000^{* *}$ & -0.463 & $0.000^{* *}$ \\
\hline PDJ_EXPECTATION & 0.049 & 0.340 & 0.047 & 0.366 & 0.044 & 0.411 \\
\hline FB & & & -0.022 & 0.676 & -0.017 & 0.740 \\
\hline FB_Outcome & & & & & -0.008 & 0.888 \\
\hline FB_Expectation & & & & & -0.059 & 0.278 \\
\hline F Statistic & & 38.549 & & 25.687 & & 15.631 \\
\hline $\mathrm{R}^{\wedge} 2$ & & 0.206 & & 0.206 & & 0.209 \\
\hline $\mathrm{AR}^{\wedge} 2$ & & 0.200 & & 0.198 & & 0.196 \\
\hline
\end{tabular}

Dependent Variable: Turnover Intentions

**Significant at $\mathrm{P}<0.05$

Model1: Direct relationship b/w distributive justice and Turnover intentions

Model2: Model2: Relationship b/w Familiness and Turnover intentions after controlling P.D. Justice

Model3: Relationship b/w interaction effects and turnover intentions after controlling main effects 
Table 5: Moderation Analysis for Pay Satisfaction

FB Moderation on Pay Satisfaction

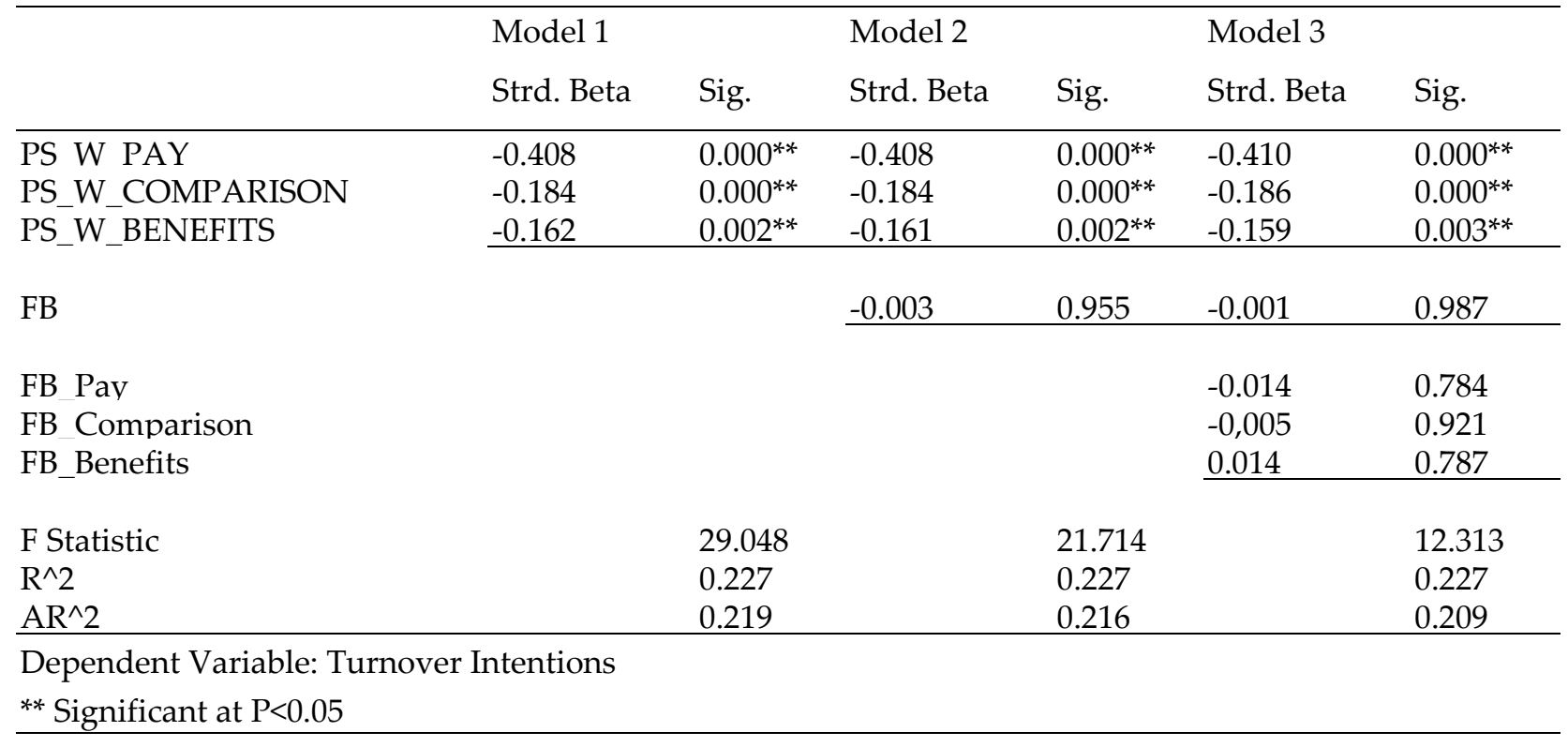

Model1: Direct relationhsip b/w pay satisfaction and turnover intentions

Model2: Model2: Relationship b/w Familiness and Turnover intentions after controlling Pav Satisf.

Model3: Relationshop b/w interaction effects and turnover intentions after controlling main effects

\section{DISCUSSION}

The analysis revealed significant findings about HR issues of family businesses, particularly about pay satisfaction and justice perceptions. Although there is evidence in the literature to support Hypothesis 1 (Beehr et al., 1997; Carmon et al., 2010) that family business employees are less satisfied with justice than non-family business employees, our findings are not supporting it. According to results, there is no difference between family business blue-collar employees' distributive justice perceptions and that of non-family business bluecollar employees. Although Beehr et al. (1997) and Carmon et al. (2010) suggested that family business employees might suffer from injustice, and Atalay \& Özler (2013) argued that family business employees benefit from organizational justice, in the case of blue-collar workers, family ownership or management does not make a significant impact on organizational justice perceptions.

Findings about pay perceptions of blue-collar family business employees revealed significant results. Past literature (i.e., Block et al., 2015; Carrasco-Hernandez \& Sánchez-Marín, 2007) suggests that family business employees are paid less and are less satisfied with compensation packages, which is partially confirmed by this work. According to the results, family business employees are not significantly dissatisfied with their salaries as well as in comparison with other employees, but they are less satisfied with their benefit packages.

Based on previous literature (R. S. Reid \& Adams, 2001), family business employees should have higher turnover intentions, but results show no significant difference between family business employees and non-family business employees. This result is not unexpected after finding no significant difference on distributive justice and pay satisfaction between family business employees and non-family business employees. Therefore, it appears that family business and non-family business blue-collar employees do not differ in their turnover intentions.

Barnett \& Kellermanns (2006) argued that family involvement might not affect justice perceptions directly and other researchers (i.e., Astrachan \& Kolenko, 1994; R. S. Reid \& Adams, 2001; Schulze et al., 2003; John L. Ward, 1988) investigated how family involvement might impact satisfaction and justice perceptions. In this study, the researchers explored moderator analysis for family involvement. According to results from Table 4, family 
involvement does not have a significant impact on the relationship between distributive justice, perceived pay satisfaction, and turnover intentions of family business blue-collar employees.

\section{MANAGERIAL IMPLICATIONS}

This exploratory research on blue-collar workers provided many compelling results for family business managers as well as for non-family business managers. It is promising to see that family businesses do not differ from non-family businesses in organizational justice perceptions like some of the previous literature suggested. However, family businesses should strive for higher justice perceptions to reduce the chance of impacting the family reputation and image.

It is encouraging that family businesses do not differ from non-family businesses in pay satisfaction level. Based on the results, family businesses should pay more attention to their benefit packages. Employees who are less satisfied with benefit packages might begin to have higher turnover intentions and eventually leave the organization. This might result in loss of talent and knowledge, easily leading to problems for the business.

\section{LIMITATIONS AND FUTURE RESEARCH}

In today's realm of data collection, it is difficult for many researchers to obtain longitudinal data for extensive analysis. Hence, studies suffer due to the limitations of cross-sectional data, which is one of the main limitations of this study. Furthermore, data was collected for a broader analysis of blue-collar workers; hence family firm classifications were not applied to the criteria in most of the literature. Family businesses are identified by the personal confirmation of survey respondents. Therefore, future studies should focus on collecting detailed information on family ownership and the familiness effect and analysing the results according to the familiness scale (i.e., Klein, Astrachan \& Smyrnios, 2005).

\section{CONCLUSION}

Analysis of family business characteristics compared with non-family businesses is vital for family business literature. Particularly, the impact of familiness on non-family employees is very important to understand family firm dynamics. This study enlightened this part of the family business research by comparing family business blue-collar employees with non-family counterparts. Results show that family firms are neither too good to work, nor too difficult to be in. There is no difference in justice perceptions as well as turnover intentions of family business employees compared to non-family business employees. Furthermore, while family firm employees are satisfied with salary, they are not satisfied with the benefit packages. This shows that, while family firms pay their employees according to the industry standards, they don't provide extra benefit packages to reserve the money in the business.

\section{REFERENCES}

Al-Salemi, A. M. A. (2013). The impact of organizational justice on employee turnover, using Total E\&P Yemen. African Journal of Business Management, 7(37), 3810-3826. https://doi.org/10.5897/AJBM12.1424

Alexander, S., \& Ruderman, M. (1987). The role of procedural and distributive justice in organizational behaviour. Social Justice Research, 1(2), 177-198. https://doi.org/10.1007/BF01048015

analysis of human resource strategies in family and non-family businesses. Journal of Small Business and Enterprise Development, 9(3), 245-259. https://doi.org/10.1108/14626000210438571

Astrachan, J. H., \& Kolenko, T. A. (1994). A Neglected Factor Explaining Family Business Success: Human Resource Practices. Family Business Review, 7(3), 251-262. https://doi.org/10.1111/j.1741-6248.1994.00251.x

Atalay, C. G., \& Özler, D. U. (2013). A Research To Determine The Relationship Between Organizational Justice and Psychological Ownership Among Non-Family Employees in a Family Business. Procedia-Social and Behavioural Sciences, 99, 247-256. https://doi.org/10.1016/j.sbspro.2013.10.492

Bandiera, O., Guiso, L., Prat, A., \& Sadun, R. (2015). Matching firms, managers, and incentives. Journal of Labor Economics, 33(3), 623-681. 
Barnett, T., \& Kellermanns, F. W. (2006). Are We Family and Are We Treated as Family? Nonfamily Employees' Perceptions of Justice in the Family Firm. Entrepreneurship Theory and Practice, 30(6), 837-854. https://doi.org/10.1111/j.1540-6520.2006.00155.x

Bassanini, A., Breda, T., Caroli, E., \& Rebérioux, A. (2013). Working in family firms: Paid less but more secure? Evidence from French matched employer-employee data. ILR Review, 66(2), 433-466.

Beehr, T. A., Drexler, J. A., \& Faulkner, S. (1997). Working in small family businesses: empirical comparisons to non-family businesses. Journal of Organizational Behavior, 18(3), 297-312.

Block, J. H., Millán, J. M., Román, C., \& Zhou, H. (2015). Job Satisfaction and Wages of Family Employees. Entrepreneurship Theory and Practice, 39(2), 183-207. https://doi.org/10.1111/etap.12035

Carlson, D. S., Upton, N., \& Seaman, S. (2006). The Impact of Human Resource Practices and Compensation Design on Performance: An Analysis of Family-Owned SMEs. Journal of Small Business Management, 44(4), 531-543. https://doi.org/10.1111/j.1540-627X.2006.00188.x

Carmon, A. F., Miller, A. N., Raile, A. N. W., \& Roers, M. M. (2010). Fusing family and firm: Employee perceptions of perceived homophily, organizational justice, organizational identification, and organizational commitment in family businesses. Journal of Family Business Strategy, 1(4), 210-223. https://doi.org/10.1016/j.jfbs.2010.10.003

Carrasco-Hernandez, A., \& Sánchez-Marín, G. (2007). The Determinants of Employee Compensation in Family Firms: Empirical Evidence. Family Business Review, 20(3), 215-228. https://doi.org/10.1111/j.17416248.2007.00096.x

Carsrud, A. L. (2006). Commentary: "Are We Family and Are We Treated as Family? Nonfamily Employees" Perceptions of Justice in the Family Firm": It All Depends on Perceptions of Family, Fairness, Equity, and Justice." Entrepreneurship Theory and Practice, 30(6), 855-860. https://doi.org/10.1111/j.15406520.2006.00156.x

Chen, G., Ployhart, R. E., Cooper-Thomas, H., Anderson, N. R., \& Bliese, P. D. (2011). The Power of Momentum: A New Model of Dynamic Relationships Between Job Satisfaction Change and Turnover Intentions. Academy of Management Journal, 54(1), 154-181. https://doi.org/10.5465/AMJ.2011.59215089

Chrisman, J. J., Chua, J. H., \& Litz, R. (2003). A unified systems perspective of family firm performance: an extension and integration. Journal of Business Venturing, 18, 467-472. https://doi.org/10.1016/S08839026(03)00055-7

Chrisman, J. J., Chua, J. H., Pearson, A. W., \& Barnett, T. (2012). Family Involvement, Family Influence, and Family-Centered Non-Economic Goals in Small Firms. Entrepreneurship Theory and Practice, 36(2), 267-293. https://doi.org/10.1111/j.1540-6520.2010.00407.x

Chrisman, J. J., Devaraj, S., \& Patel, P. C. (2017). The Impact of Incentive Compensation on Labor Productivity in Family and Nonfamily Firms. Family Business Review, 30(2), 119-136. https://doi.org/10.1177/0894486517690052

Chua, J. H., Chrisman, J. J., \& Sharma, P. (2003). Succession and Nonsuccession Concerns of Family Firms and Agency Relationship with Nonfamily Managers. Family Business Review, 16(2), 89-107. https://doi.org/10.1111/j.1741-6248.2003.00089.x

Cruz, C., Firfiray, S., \& Gomez-Mejia, L. R. (2011). Socioemotional wealth and human resource management (HRM) in family-controlled firms. Research in personnel and human resources management, 30(1), 159-217.

DeConinck, J. B., \& Stilwell, C. D. (2004). Incorporating organizational justice, role states, pay satisfaction and supervisor satisfaction in a model of turnover intentions. Journal of Business Research, 57(3), 225-231. https://doi.org/10.1016/S0148-2963(02)00289-8

Dulebohn, J. H., \& Werling, S. E. (2007). Compensation research past, present, and future. Human Resource Management Review, 17(2), 191-207. https://doi.org/10.1016/j.hrmr.2007.03.002

Ercan, S. (2018). Emirati women's experience of job satisfaction: Comparative effects of intrinsic and extrinsic factors. South African Journal of Business Management, 49(1). https://doi.org/10.4102/sajbm.v49i1.4 
Fama, E. F., \& Jensen, M. C. (1983). Agency Problems and Residual Claims. The Journal of Law \& Economics, Vol. 26, pp. 327-349. https://doi.org/10.2307/725105

Gersick, K. E., Davis, J. A., Hampton, M. M., \& Lansberg, I. (1997). Generation to generation: Life cycles of the family business. Harvard Business Press.

Gomez-Mejia, L. R, \& Balkin, D. B. (2006). Compensation, organizational strategy, and firm performance. Cincinnati, OH: South- Western Publishing.

Gomez-Mejia, Luis R., Larraza-Kintana, M., \& Makri, M. (2003). The Determinants of Executive Compensation in Family-Controlled Public Corporations. Academy of Management Journal, 46(2), 226-237. https://doi.org/10.5465/30040616

Gomez-Mejia, Luis R., Nuñez-Nickel, M., \& Gutierrez, I. (2001). The Role of Family Ties in Agency Contracts. Academy of Management Journal, 44(1), 81-95. https://doi.org/10.5465/3069338

Gottschalck, N., Guenther, C., \& Kellermanns, F. (2019). For whom are family-owned firms good employers? An exploratory study of the turnover intentions of blue- and white-collar workers in family-owned and non-family-owned firms. Journal of Family Business Strategy, xxxx, 1-13. https://doi.org/10.1016/j.jfbs.2019.02.004

Haar, J. M., \& Spell, C. S. (2009). How does distributive justice affect work attitudes? The moderating effects of autonomy. The International Journal of Human Resource Management, 20(8), 1827-1842. https://doi.org/10.1080/09585190903087248

Hair, J. F., Black, W. C., Babin, B. J., \& Anderson, R.(2010). Multivariate Data Analysis (7th ed). Upper Saddle River: Prentice Hall.

Heneman III, H. G., \& Schwab, D. P. (1985). Pay satisfaction: Its multidimensional nature and measurement. International journal of Psychology, 20(1), 129-141.

Kachaner, N., Stalk, G., \& Bloch, A. (2012). What you can learn from family Business. Harvard Business Review, 90(11), 102-106.

Klein, S. B., Astrachan, J. H., \& Smyrnios, K. X. (2005). The F-PEC Scale of Family Influence: Construction, Validation, and Further Implication for Theory. Entrepreneurship Theory and Practice, 29(3), 321-339. https://doi.org/10.1111/j.1540-6520.2005.00086.x

Konovsky, M. A., Folger, R., \& Cropanzano, R. (1987). Relative Effects of Procedural and Distributive Justice on Employee Attltudes. In Representative Research in Social Psychology (Vol. 17).

Lubatkin, M. H., Ling, Y., \& Schulze, W. S. (2007). An Organizational Justice-Based View of Self-Control and Agency Costs in Family Firms. Journal of Management Studies, 44(6), 955-971. https://doi.org/10.1111/j.14676486.2006.00673.x

Madison, K., Daspit, J. J., Turner, K., \& Kellermanns, F. W. (2018). Family firm human resource practices: Investigating the effects of professionalization and bifurcation bias on performance. Journal of Business Research, 84, 327-336.

Memili, E., \& Welsh, D. H. B. (2012). Towards a theory of nonfamily employees' organizational identification and attachment in family firms. Journal of Technology Management in China, 7(3), 255-269. https://doi.org/10.1108/17468771311325167

Memili, E., Misra, K., Chang, E. P., \& Chrisman, J. J. (2013). The propensity to use incentive compensation for non- family managers in SME family firms. Journal of Family Business Management, 3(1), 62-80.

Michiels, A. (2017). Formal compensation practices in family SMEs. Journal of Small Business and Enterprise Development, 24(1), 88-104. https://doi.org/10.1108/JSBED-12-2015-0173

Neckebrouck, J., Schulze, W., \& Zellweger, T. (2018). Are family firms good employers? Academy of Management Journal, 61(2), 553-585.

Nelson, M. F., Stone, T. H., Frye, C. M., \& Chown, D. W. (2008). Pay Me More. Compensation \& Benefits Review, 40(2), 35-42. https://doi.org/10.1177/0886368708314075 
Nielson, B. (2014). An empirical assessment of employee pay satisfaction and personality using equity theory and discrepancy theories. (doctoral dissertation). Jackson State University.

Pittino, D., Visintin, F., Lenger, T., \& Sternad, D. (2016). Are high performance work practices really necessary in family SMEs? An analysis of the impact on employee retention. Journal of Family Business Strategy, 7(2), 75-89.

Reid, R. S., \& Adams, J. S. (2001). Human resource management-a survey of practices within family and nonfamily firms. Journal of European Industrial Training, 25(6), 310-320. https://doi.org/10.1108/03090590110401782

Reid, R., Morrow, T., Kelly, B. and McCartan, P. (2002), "People management in SMEs: an analysis of human resource strategies in family and non-family businesses", Journal of Small Business and Enterprise Development, 9(3), 245-259.

Rogelberg, S. G., \& Stanton, J. M. (2007). Introduction. Organizational Research Methods, 10(2), 195-209. https://doi.org/10.1177/1094428106294693

Samara, G., \& Arenas, D. (2017). Practicing fairness in the family business workplace. Business Horizons, 60(5), 647-655.

Samara, G., Jamali, D., \& Parada, M. J. (2019). Antecedents and outcomes of bifurcated compensation in family firms: A multilevel view. Human Resource Management Review, October 2019, 100728. https://doi.org/10.1016/j.hrmr.2019.100728

Schulze, W. S., Lubatkin, M. H., \& Dino, R. N. (2003). Toward a theory of agency and altruism in family firms. Journal of Business Venturing, 18(4), 473-490. https://doi.org/10.1016/S0883-9026(03)00054-5

Sieger, P., Bernhard, F., \& Frey, U. (2011). Affective commitment and job satisfaction among non-family employees: Investigating the roles of justice perceptions and psychological ownership. Journal of Family Business Strategy, 2(2), 78-89. https://doi.org/10.1016/j.jfbs.2011.03.003

Ward, J. (2016). Keeping the family business healthy: How to plan for continuing growth, profitability, and family leadership. Springer.

Ward, John L. (1988). The Special Role of Strategic Planning for Family Businesses. Family Business Review, 1(2), 105-117. https://doi.org/10.1111/j.1741-6248.1988.00105.x

Werner, S., \& Tosi, H. L. (1995). Other People's Money: The Effects of Ownership on Compensation Strategy and Managerial Pay. Academy of Management Journal, 38(6), 1672-1691. https://doi.org/10.5465/256849

Williams, M. L., Brower, H. H., Ford, L. R., Williams, L. J., \& Carraher, S. M. (2008). A comprehensive model and measure of compensation satisfaction. Journal of Occupational and Organizational Psychology, 81(4), 639-668. https://doi.org/10.1348/096317907X248851 